\title{
The Synthetic Dipeptide Pidotimod Shows a Chemokine-Like Activity through CXC Chemokine Receptor 3 (CXCR3)
}

\author{
Francesca Caccuri ${ }^{1}$, Antonella Bugatti ${ }^{1}$, Silvia Corbellini ${ }^{2}$, Sara Roversi ${ }^{1}$, Alberto Zani ${ }^{1}$, \\ Pietro Mazzuca $^{1}$, Stefania Marsico ${ }^{3} \mathbb{D}$, Arnaldo Caruso ${ }^{1}$ and Cinzia Giagulli ${ }^{1, * \mathbb{D}}$ \\ 1 Section of Microbiology, Department of Molecular and Translational Medicine, University of Brescia, \\ 25123 Brescia, Italy; francesca.caccuri@unibs.it (F.C.); antonella.bugatti@unibs.it (A.B.); \\ s.roversi003@unibs.it (S.R.); a.zani033@unibs.it (A.Z.); p.mazzuca@unibs.it (P.M.); \\ arnaldo.caruso@unibs.it (A.C.) \\ 2 Laboratory of Microbiology and Virology, Azienda Socio Sanitaria Territoriale Spedali Civili, \\ 25123 Brescia, Italy; silvia.corbellini@gmail.com \\ 3 Department of Pharmacy, Health and Nutritional Sciences, University of Calabria, Arcavacata di Rende, \\ 87036 Cosenza, Italy; stefania.marsico@unical.it \\ * Correspondence: cinzia.giagulli@unibs.it; Tel.: +39-030-399-6698; Fax: +39-030-395-258
}

Received: 9 October 2019; Accepted: 22 October 2019; Published: 24 October 2019

\begin{abstract}
In recent years immunomodulators have gained a strong interest and represent nowadays an active expanding area of research for the control of microbial diseases and for their therapeutic potential in preventing, treating and reducing the morbidity and mortality of different diseases. Pidotimod (3-L-pyroglutamyl-L-thiaziolidine-4carboxylic acid, PDT) is a synthetic dipeptide, which possesses immunomodulatory properties and exerts a well-defined pharmacological activity against infections, but its real mechanism of action is still undefined. Here, we show that PDT is capable of activating tyrosine phosphorylation-based cell signaling in human primary monocytes and triggering rapid adhesion and chemotaxis. PDT-induced monocyte migration requires the activation of the PI3K/Akt signaling pathway and chemokine receptor CXCR3. Indeed, a mAb to CXCR3 and a specific receptor inhibitor suppressed significantly PDT-dependent chemotaxis, and CXCR3-silenced primary monocytes lost responsiveness to PDT chemoattraction. Moreover, our results highlighted that the PDT-induced migratory activity is sustained by the CXCR3A isoform, since CXCR3-transfected L1.2 cells acquired responsiveness to PDT stimulation. Finally, we show that PDT, as CXCR3 ligands, is also able to direct the migration of IL-2 activated T cells, which express the highest levels of CXCR3 among CXCR3-expressing cells. In conclusion, our study defines a chemokine-like activity for PDT through CXCR3A and points on the possible role that this synthetic dipeptide may play in leukocyte trafficking and function. Since recent studies have highlighted diverse therapeutic roles for molecules which activates CXCR3, our findings call for an exploration of using this dipeptide in different pathological processes.
\end{abstract}

Keywords: pidotimod; CXCR3; monocyte; migration; PI3K/Akt pathway; T cell; immunomodulant

\section{Introduction}

Viruses are the main agents responsible for Acute Respiratory Tract Infections (ARTIs) during the pediatric age [1]. The introduction of new antibiotics and vaccines has surely contributed to control the most life-threatening ARTIs but has not had a strong impact on viral ARTIs. Therefore, one efficient approach in preventing and treating ARTIs is to increase the immune response by enhancing the child's innate defense mechanisms. The last decade has seen the emergence of different kinds of natural 
and synthetic molecules with different mechanisms of action, called immunomodulators, which have been introduced for prophylaxis and treatment of various infectious diseases and inflammation [2-6]. Some of these substances are granulocyte colony-stimulating factor (G-CSF), interferons, imiquimod and bacterial-derived preparations, which are already licensed for use in patients. Others including IL-12, various chemokines, synthetic cytosine phosphate-guanosine $(\mathrm{CpG})$ oligodeoxynucleotides and glucans, have been investigated extensively in clinical and preclinical studies [7]. Another compound, which exerts a well-defined immunomodulatory and antimicrobial activity against infections is Pidotimod (3-L-pyroglutamyl-L-thiaziolidine-4carboxylic acid, PDT) [8,9], a synthetic dipeptide on which research focused particular attention for its properties in prevention and treatment of ARTIs in childhood. Indeed, different studies have shown that PDT exerts a beneficial effect in children reducing the number of ARTIs, the severity of signs and symptoms of acute episodes [8,10-14].

In vitro studies, performed using either murine or human cells, have shown that PDT is able to modulate both innate and adaptive immune responses [15]. In particular, this dipeptide upregulates the expression of HLA-DR and of the co-stimulatory molecules CD83 and CD86 on dendritic cells (DCs) inducing their maturation. It also stimulates DCs to release pro-inflammatory molecules, stimulates natural killer cell activity, inhibits thymocyte apoptosis and potentiates phagocytosis [16-19]. This dipeptide has also been described to enhance the proliferation of mitogen-activated peripheral blood mononuclear cells (PBMCs) and increase the production of cytokines, as IFN- $\alpha$, IFN- $\gamma$ and IL-12, crucial to drive $\mathrm{T}$ cell proliferation and differentiation towards a Th1 phenotype $[16,19,20]$. More recently, Fogli et al. (2014) showed that the treatment of PBMCs and monocytes with PDT led to a significant attenuation of the inflammatory response to TLR agonists. Since TLRs are key components in pathogen recognition and critical mediators in the early response to foreign microorganisms, attenuation of the inflammatory response to TLR agonists by PDT represents an important immunomodulating effect [21].

Currently, the research focused on this molecule has attempted to better elucidate its mechanism of action. The ability of PDT to modulate different aspects of both innate and adaptive immune response leaves to speculate that this dipeptide might exert its function through the involvement of one or more cytokine/chemokine receptors. Indeed, these receptors play an essential role in the immune response and are responsible for activation and recruitment of immune cells at infection and inflammation sites, contributing to the induction and exacerbation of chronic inflammatory reactions. However, despite the numerous efforts, there are limited information about the cellular receptor(s) engaged on immune cells and intracellular signaling pathways triggered by this molecule. Currently, a new research input could be now essential on the role of PDT as immunomodulant, since immunomodulation represents an adjunct modality which looks promising for control of microbial diseases and in the future could play a key role in treating and reducing the morbidity and mortality of different diseases.

In this study we investigated the PDT mechanism of action, thus, to better understand how this dipeptide exerts its biological activities and the why of its efficacy and safety.

Here, we demonstrate that PDT shows a chemokine-like activity through the activation of CXCR3 receptor, in particular CXCRA isoform, and of the PI3K/Akt signaling pathway.

\section{Results}

PDT activates rapid intracellular tyrosine phosphorylation-based protein signaling on human primary monocytes.

Rapid phosphorylation of signaling proteins is triggered by immune cell surface receptors and plays a pivotal role in the regulation of innate and adaptive immune functions. In particular, tyrosine phosphorylation (pTyr) of signaling proteins is indispensable in the regulatory pathways and represents a key activation signal, promoted by cytokine/chemokine receptors [22-24]. Therefore, in order to understand if PDT is able to trigger a cytokine/chemokine receptor, we investigated its capability to activate in a few min tyrosine phosphorylation-based cell signaling on human primary monocytes. 
To this aim monocytes were stimulated at $37^{\circ} \mathrm{C}$ for $5 \mathrm{~min}$ with the dipeptide PDT at different concentrations $(1,5,25,50,100 \mu \mathrm{g} / \mathrm{mL})$ and the tripeptide fMLP $(10 \mathrm{nM})$, used as positive control. Data obtained from western blot analysis, using a protein specific anti-phosphotyrosine antibody, show that extracts from untreated cells have a low basal level of Tyr phosphorylated proteins. At the same time, PDT dose-response analysis shows that the immunomodulant is able to trigger a rapid increase of Tyr phosphorylated proteins at concentrations ranging from 5 to $100 \mu \mathrm{g} / \mathrm{mL}$ (Figure 1). As expected, fMLP induced a significant level of Tyr phosphorylated proteins.

These data show the PDT ability to induce protein tyrosine phosphorylation in monocytes and suggest the capability of the dipeptide to act probably through a cytokine/chemokine receptor activation.
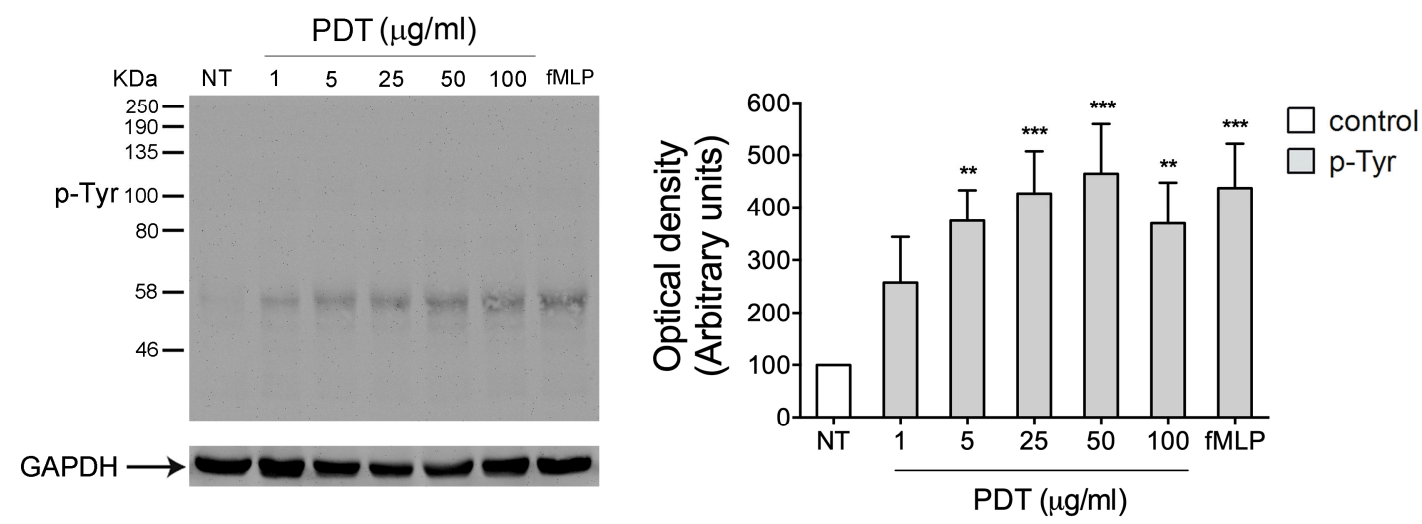

Figure 1. Effect of PDT stimulation on protein tyrosine phosphorylation in monocytes. Monocytes were treated for $5 \mathrm{~min}$ with 1, 5, 25, 50, $100 \mu \mathrm{g} / \mathrm{mL}$ of PDT and $10 \mathrm{nM}$ of fMLP. Untreated cells were used as control (NT). Western blot analysis of cells lysates shows that PDT is able to induce an increase of Tyr phosphorylated proteins at different concentrations tested, as shown by densitometry analysis and plotting of the pTyr/GAPDH. In the left panel blots from one representative experiment of three with similar results are shown. In the right panels, values reported for protein Tyr phosphorylation are the mean \pm SD of three independent experiments. Statistical analysis was performed by one-way ANOVA and the Bonferroni's post-test was used to compare data, ${ }^{* *} p<0.01,{ }^{* * *} p<0.001$.

\subsection{PDT Induces Monocyte Adhesion and Migration}

Chemokines, through chemokine receptor activation, trigger intracellular signaling events, which control leukocyte recruitment, a key multi-step process in regulation of immune responses involving rapid integrin-dependent adhesion and migration of leukocytes [25]. In order to assess the ability of PDT to functionally activate a chemokine receptor on monocytes, we performed static adhesion and migration assays. Static adhesion assays were performed on immobilized ligands, as ICAM- 1 and VCAM-1, in response to different concentration of the synthetic dipeptide $(1,5,10,50,100 \mu \mathrm{g} / \mathrm{mL})$. Figure 2 shows that PDT triggered a rapid $(2 \mathrm{~min})$ concentration-dependent adhesion of primary human monocytes to ICAM-1 (Figure 2A) and V-CAM (Figure 2B). In particular, PDT significantly stimulated monocyte adhesion on ICAM- 1 at a concentration ranging from $10-50 \mu \mathrm{g} / \mathrm{mL}$ with a peak at $10 \mu \mathrm{g} / \mathrm{mL}$ (Figure 2A). On the other hand, PDT-induced adhesion on VCAM-1 occurred at a lower concentration, ranging from 5 to $10 \mu \mathrm{g} / \mathrm{mL}$ and reaching a peak at $5 \mu \mathrm{g} / \mathrm{mL}$ (Figure 2B).

Then, we performed monocyte migration in Transwell chemotaxis assays in response to different concentrations of the dipeptide $(0.05,0.1,0.5,1,5,25 \mu \mathrm{g} / \mathrm{mL})$. In Figure $2 \mathrm{C}$ we show that PDT stimulates chemoattraction of monocytes at a concentration ranging between 0.1 and $5 \mu \mathrm{g} / \mathrm{mL}$.

These data show that monocyte adhesion requires a higher PDT concentration than that required for chemotaxis. This phenomenon is common to chemokines and can be elucidated by the findings of Campbell et al. (1996), who demonstrated that adhesion requires a high agonist concentration with the simultaneous occupancy of many receptors, whereas chemotaxis occurs at low agonist concentration. These different requirements for triggering adhesion and chemotaxis are necessary for their independent regulation [26]. 
Overall, these results show the capability of PDT to stimulate rapid adhesion and migration of human primary monocytes, suggesting a chemokine-like role for the dipeptide and its ability to transduce, through a chemokine receptor, intracellular signals involved in regulation of cell motility.

A

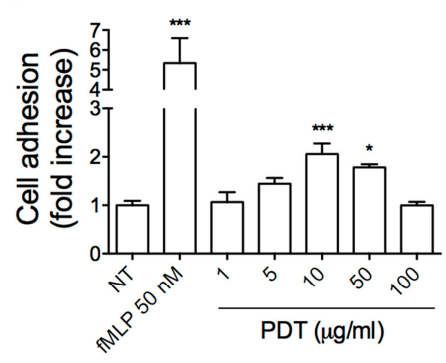

B

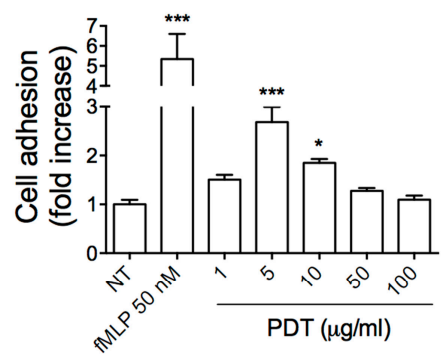

C

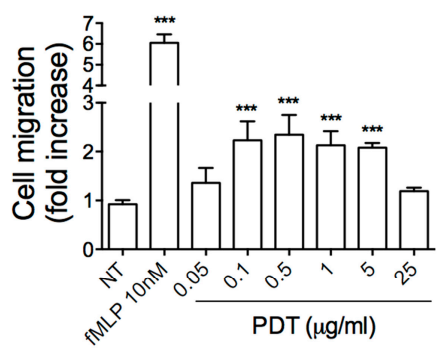

Figure 2. Effect of PDT on monocytes adhesion and migration. (A,B) Static adhesion assay on ICAM-1 (A) and VCAM-1 (B). Monocytes were stimulated or not (NT) for 2 min at $37^{\circ} \mathrm{C}$ with PDT at the indicated concentrations. Bars represent the means \pm SD of 3 independent experiments performed in triplicate. Statistical analysis was performed by one-way ANOVA and the Bonferroni's post-test was used to compare data, ${ }^{* * *} p<0.001, * p<0.05$. (C) Transwell migration assays of monocytes in response to the indicated treatments. Bars represent the means $\pm \mathrm{SD}$ of 3 independent experiments performed in triplicate. Statistical analysis was performed by one-way ANOVA and the Bonferroni's post-test was used to compare data, ${ }^{* * *} p<0.001$. NT $=$ not treated.

\subsection{PTx Treatment Inhibits PDT-Induced Chemokine Activity and Tyrosine Phosphorylation-based Protein} Signaling in Monocytes

Chemokines bind and signal through seven-transmembrane receptors coupled with the Gi class of heterotrimeric G proteins. Pertussis toxin (PTx) is known to prevent the Gi proteins interaction with $G$ protein-coupled receptors, thus blocking intracellular signaling cascade. In order to determine if PDT receptor is coupled to Gi proteins, monocytes were pretreated with $500 \mathrm{ng} / \mathrm{mL}$ of PTx for $2 \mathrm{~h}$ at 37 ${ }^{\circ} \mathrm{C}$, then stimulated with the dipeptide and tested for their capability to adhere, migrate and trigger phosphorylation-based cell signaling.

PDT-triggered monocyte adhesion on ICAM- 1 and migration were completely inhibited by PTx pretreatment (Figure $3 \mathrm{~A}$ and $3 \mathrm{C}$, respectively). In the same assays, as expected, the strong adhesion and chemotaxis induced by fMLP (100 nM and $10 \mathrm{nM}$, respectively), a reference chemoattractant able to transduce intracellular signals through Gi proteins, was inhibited by PTx (Figure 3A,C) [26-28]. The inhibitory effect of PTx was not attributable to a generic toxic effect of PTx pretreatment, because adhesion of monocytes was retained after $10 \mathrm{~min}$ of PMA (phorbol 12-myristate 13-acetate) stimulation (100 ng/mL) (Figure 3B), and cell migration occurred in response to LPC (L- $\alpha$-lysophosphatidylcholine, palmitoyl C16:0, Sigma-Aldrich) $(10 \mu \mathrm{M})$ (Figure 3C), in line with previous observations [27,29,30].

In addition, to determine if rapid tyrosine phosphorylation-based protein signaling triggered by the dipeptide was dependent from a receptor coupled with Gi proteins, monocytes were pretreated with PTx, then stimulated with PDT $(5 \mu \mathrm{g} / \mathrm{mL})$ and tested for their capability to induce protein tyrosine phosphorylation. Data obtained from western blot analysis, using a protein specific anti-phosphotyrosine antibody, showed that PDT-triggered protein tyrosine phosphorylation was completely inhibited by PTx pretreatment (Figure 3D).

Overall, these data showed that PDT induces monocyte adhesion, migration and intracellular protein tyrosine phosphorylation through a cell surface receptor coupled with the Gi class of heterodimeric $G$ proteins. 
A

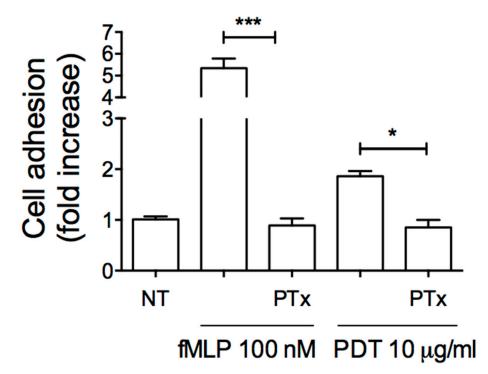

D

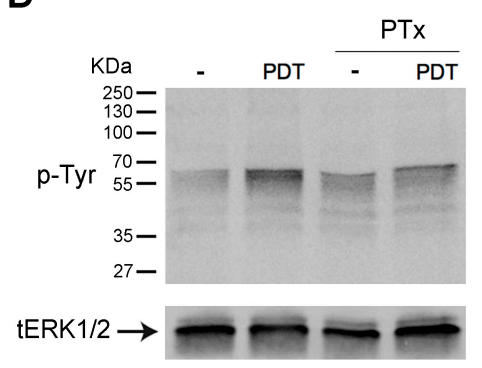

B
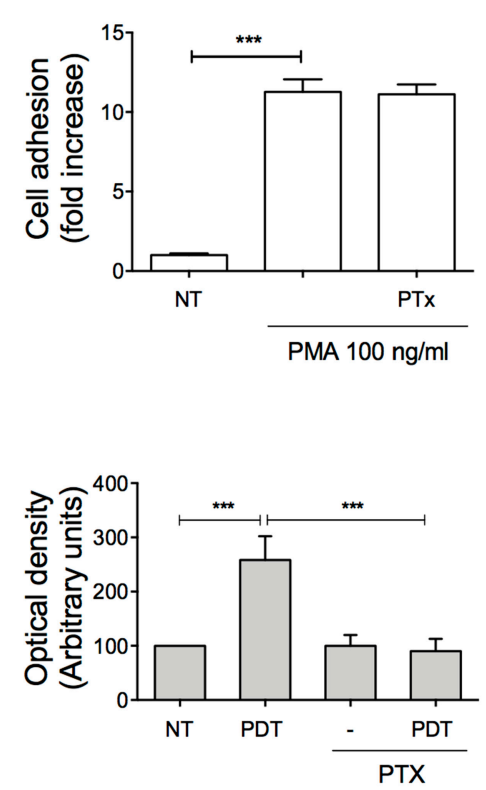

C

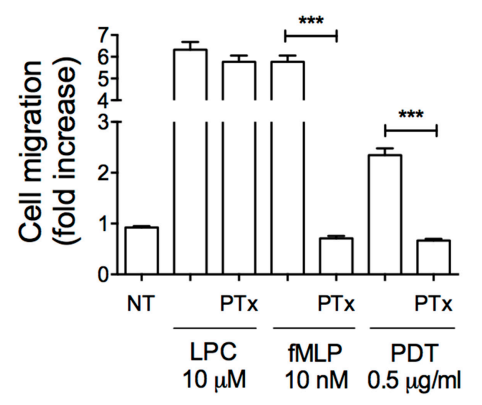

Figure 3. Effect of PTx on PDT-induced monocytes adhesion, migration and protein tyrosine phosphorylation. (A, B) Static adhesion assay of monocytes on ICAM-1. Cells pretreated with $500 \mathrm{ng} / \mathrm{mL}$ of PTx for $2 \mathrm{~h}$ at $37^{\circ} \mathrm{C}$ were stimulated for $2 \mathrm{~min}$ at $37^{\circ} \mathrm{C}$ with PBS (NT), fMLP (100 $\mathrm{nM})$, PDT $(10 \mu \mathrm{g} / \mathrm{mL})(\mathbf{A})$ or for $10 \mathrm{~min}$ with PMA $(100 \mathrm{ng} / \mathrm{mL})(\mathbf{B})$. Bars represent the means $\pm \mathrm{SD}$ of 3 independent experiments performed in triplicate. Statistical analysis was performed by paired 2-tail Student $t$ test, ${ }^{* * *} p<0.001,{ }^{*} p<0.05$. (C) Transwell migration assay of monocytes in response to the indicated treatments. Monocytes pretreated with PTx were stimulated for $90 \mathrm{~min}$ at $37^{\circ} \mathrm{C}$ with PBS (NT), LPC $(10 \mu \mathrm{M})$, fMLP $(10 \mathrm{nM})$ or PDT $(0.5 \mu \mathrm{g} / \mathrm{mL})$. Bars represent the means \pm SD of 3 independent experiments performed in triplicate. Statistical analysis was performed by paired 2-tail Student $t$ test, $* * * p<0.001$. (D) Monocytes pretreated or not with PTx were stimulated or not for $5 \mathrm{~min}$ at $37^{\circ} \mathrm{C}$ with PDT $(5 \mu \mathrm{g} / \mathrm{mL})$. Western blot analysis of cell lysates shows that PDT-triggered protein tyrosine phosphorylation was inhibited by PTx, as shown by densitometry analysis and plotting of the pTyr/tERK1/2. In the left panel blots from one representative experiment of three with similar results are shown. In the right panels, values reported for protein Tyr phosphorylation are the mean \pm SD of three independent experiments. Statistical analysis was performed by paired 2-tail Student $t$ test and the Bonferroni's post-test was used to compare data, ${ }^{* * *} p<0.001$. NT $=$ not treated.

\subsection{Monocyte Migration Triggered by PDT Requires the Activation of PI3K/Akt Signaling Pathway}

Cell migration is governed by a complex network of signal transduction pathways, which involve lipid second messengers, small GTPases, kinases, cytoskeleton-modifying proteins, and culminates in the cytoskeletal remodeling and chemoattraction response to ligand-induced receptor activation [31]. In order to investigate the possible signaling pathways responsible for monocyte recruitment triggered by PDT stimulation, primary human monocytes were pretreated for $60 \mathrm{~min}$ at $37^{\circ} \mathrm{C}$ with inhibitors of different key signaling molecules and then stimulated with the dipeptide $(0.5 \mu \mathrm{g} / \mathrm{mL})$ to migrate in a Transwell chemotaxis system. As shown in the Figure 4A, AG490 $(10 \mu \mathrm{M})$, a specific and potent inhibitor of the Janus kinase 2 protein (JAK2), as well as PD98059 (10 $\mu \mathrm{M})$, a MAP kinase/extracellular signal-regulated kinase (ERK) inhibitor, and staurosporine, a strong inhibitor of Protein Kinase $C$ (PKC) and other protein kinases, did not impact on monocyte migration induced by PDT (Figure 4A). On the other hand, PDT-triggered monocyte migration was completely inhibited by two specific inhibitors of PI3K (wortmannin $100 \mathrm{nM}$ and LY294002 $10 \mu \mathrm{M}$ ) and by the specific Akt inhibitor VIII $(1 \mu \mathrm{M})$ (Figure $4 \mathrm{~A})$. Therefore, in order to confirm the capability of PDT to activate PI3K/Akt signaling pathways, we assessed by western blot analysis the Akt phosphorylation status at Ser473 in cytosolic extracts of cells, treated for 5, 30 and $60 \mathrm{~min}$ with the dipeptide $(5 \mu \mathrm{g} / \mathrm{mL})$. As shown in Figure 4B, 
monocytes treated with PDT $(0.5 \mathrm{~g} / \mathrm{mL})$ for 30 min showed a significant Akt phosphorylation, which remained sustained up to $60 \mathrm{~min}$.

Overall, these data show that PDT-induced monocyte chemotaxis is due to the activation of the PI3K/Akt signaling pathway, which is known to be implicated in cell migration and in downstream signaling of cytokine/chemokine receptors [32,33].

A

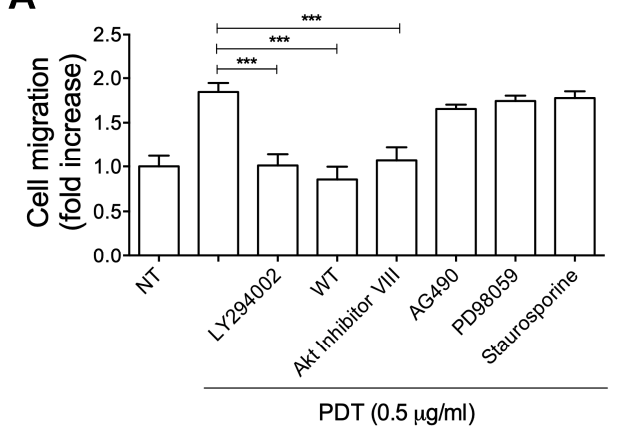

B
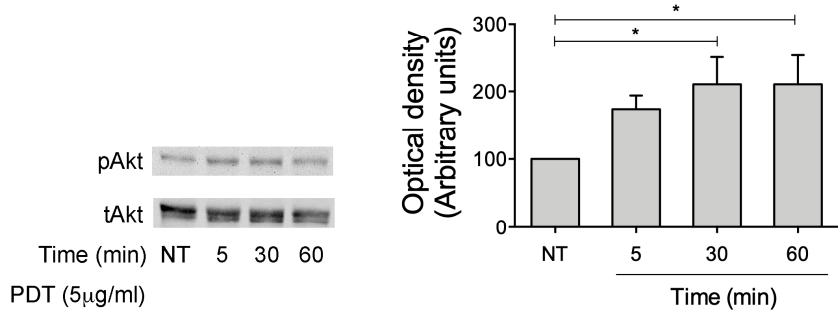

Figure 4. Signaling molecules involved in PDT-triggered monocyte migration. (A) Transwell migration assay of monocytes in response to the indicated treatments. Monocytes pretreated for $1 \mathrm{~h}$ at $37^{\circ} \mathrm{C}$ with the inhibitors LY294002 $(25 \mu \mathrm{M})$, wortmannin $(100 \mathrm{nM})$, Akt inhibitor VIII $(1 \mu \mathrm{M})$, AG490 (100 $\mu \mathrm{M})$, PD98059 $(10 \mu \mathrm{M})$ and staurosporine $(1 \mathrm{nM})$ were stimulated for $90 \mathrm{~min}$ at $37^{\circ} \mathrm{C}$ with PBS (NT) or PDT $(0.5 \mu \mathrm{g} / \mathrm{mL})$. Bars represent the means \pm SD of 3 independent experiments performed in triplicate. Statistical analysis was performed by one-way ANOVA and the Bonferroni's post-test was used to compare data, ${ }^{* * *} p<0.001$. (B) Monocytes were stimulated with $5 \mu \mathrm{g} / \mathrm{mL}$ of PDT at $37^{\circ} \mathrm{C}$ for the indicated times. Not treated cells (NT) were used as control (lane 1). Western blot analysis of monocyte lysates shows that PDT activates Akt, as shown by the respective phosphorylation state, verified by densitometric analysis and plotting of the phospho-Akt/total Akt (pAkt/tAkt). In the left panel blots from one representative experiment of three with similar results are shown. In the right panel, values reported for Akt phosphorylation are the mean \pm SD of three independent experiments. Statistical analysis was performed by one-way ANOVA and the Bonferroni's post-test was used to compare data, $* p<0.05$.

\subsection{PDT-Triggered Monocyte Migration Is Mediated by CXCR3}

Purinergic receptors are G protein-coupled receptors (GPCR) involved in several cellular functions, including cell migration and its function is mediated by Gi proteins [34]. So, in order to exclude the activation of purinergic receptors from the nucleotide release due to a PDT cytotoxic effect, we evaluate the viability of monocytes treated for $2 \mathrm{~h}$ with different concentrations of PDT $(5,25,100 \mu \mathrm{g} / \mathrm{mL})$ by CellTiter-Glo®Luminescent Cell Viability Assay, which is based on determination of intracellular ATP concentration, as indicator of metabolically active cells, and propidium iodide, which can stain nucleic acids inside of dead or damaged cells. As shown in Figure 5A,B, the cells were metabolically active at any tested concentration. Therefore, we can exclude a purinergic receptor activation by the dipeptide.

Human monocytes express numerous chemokine receptors, among which CXCR1, CXCR2, CXCR3, CXCR4 might play a role in PDT chemokine-like activity. Indeed, these receptors are coupled with the Gi class of $G$ proteins and involved in promoting monocyte migration [35-37]. Therefore, first we tested whether PDT-triggered monocyte migration could be ascribed to the activation by the dipeptide of one of these receptors.

To this aim we performed Transwell chemotaxis assays with monocytes pre-treated for $1 \mathrm{~h}$ at 37 ${ }^{\circ} \mathrm{C}$ with neutralizing mAbs to CXCR1, CXCR2, CXCR3, CXCR4 or with a control mAb. The specificity of the antibodies is reported in Supplementary Material (Figure S1). As shown in Figure 5C, mAb to CXCR3 significantly inhibited PDT-dependent chemotaxis. Moreover, no inhibition of PDT activity was observed in monocytes pre-treated with the control mAb or with mAbs to CXCR1, CXCR2 and CXCR4. 
In order to confirm the involvement of CXCR3 in monocyte migration induced by PDT, we also performed chemotaxis assays with cells pre-treated $36 \mathrm{~h}$ at $37^{\circ} \mathrm{C}$ with the CXCR3 antagonist AMG487 $(0.5 \mu \mathrm{M})$. As expected, the antagonist was able to significantly inhibit monocyte migration triggered by the dipeptide (Figure 5D). The specific effect of AMG487 was confirmed by the fact that fMLP-induced monocyte migration $(10 \mathrm{nM})$ was not influenced by the presence of this antagonist, and on the other side, CXCL11-stimulated chemotaxis $(10 \mathrm{nM})$, known to be mediated by CXCR3, was completely inhibited (Figure 5D).

To further assess the involvement of CXCR3 in PDT chemokine activity, the expression of this receptor on monocytes was suppressed by silencing, using the AMAXA nucleofection technology to deliver specific siRNAs. Efficiency of nucleofection was evaluated after $16 \mathrm{~h}$ post-nucleofection by flow cytometric analysis and showed an average of $88 \% \pm 8 \%$ nucleoporated monocytes. The effects of siRNA on CXCR3 expression were evaluated by real-time PCR analysis. As shown in Figure 5E, approximately 52\% inhibition of CXCR3 transcripts was observed in monocytes at $16 \mathrm{~h}$ after nucleofection with CXCR3 siRNAs as compared to monocytes nucleofected with scr siRNA. The CXCR3 silencing induced a significant inhibition of PDT-triggered migration of monocytes as compared to cells nucleofected with an unrelated scrambled (scr) siRNAs (Figure 5F). Moreover, as expected, a significant reduction of monocyte migratory activity to CXCL11 (10 nM) (Figure 5F), one of the physiological ligands of CXCR3, confirmed the silencing of the receptor. Finally, the specificity of CXCR3 silencing was confirmed by the finding that fMPL-induced monocyte migration $(10 \mathrm{nM})$ was not influenced by inhibition of transcripts (Figure 5F).

In conclusion, all these data suggest that PDT-triggered migratory activity of PDT is mediated by CXCR3.

\subsection{The PDT-Induced Migratory Activity Is Sustained by the CXCR3A Isoform}

CXCR3 gene is alternatively spliced, generating at least three functional isoforms differing in either their $\mathrm{N}$ or $\mathrm{C}$-terminus. The more studied CXCR3 isoforms are CXCR3A and CXCR3B. It's known that $\mathrm{G}$ protein recruitment by CXCR3 isoforms is different and leads to different signaling cascades. Indeed, CXCR3A isoform is linked to G $\alpha$ i or $\mathrm{G} \alpha \mathrm{q}$ proteins, which promote cell migration by activating the PI3K/Akt pathway [38], while CXCR3B variant has been reported to be pertussis toxin-insensitive and possibly Gs coupled [39]. Since we have established that PDT acts as a chemokine in a pertussis toxin-sensitive manner, through activation of PI3K/Akt signaling pathway, we explored if a de novo expression of CXCR3A was responsible for the dipeptide activity. To this aim, L1.2 cells were used to express CXCR3A. Cells were nucleofected with fluorescent positive control vector (pmaxGFPTM Control vector) or pTarget empty vector or expressing human CXCR3A. The efficiency of nucleofection, evaluated by flow cytometry, was found to be of $86 \% \pm 6 \%$ in 3 different experiments. Flow cytometric analysis showed that a high percentage of cells nucleofected with pTarget-CXCR3A expressed the receptor on their surface $(88 \% \pm 8 \%)$, when compared to cells nucleofected with the control empty vector. The migratory behavior of L1.2 cells expressing the empty vector and CXCR3A receptor following CXCL11 $(10 \mathrm{nM})$ or PDT stimulation $(0.5,5,50,500 \mathrm{ng} / \mathrm{mL})$ was assessed by Transwell chemotaxis assays. Figure $5 \mathrm{G}$ shows that empty vector expression did not induce cells to migrate in response to PDT or CXCL11. On the other hand, expression of CXCR3A was found to significantly promote migration in response to CXCL11, the physiological ligand of this receptor, and PDT. The migratory activity triggered by PDT in CXCR3A expressing L1.2 cells was dose dependent with a peak of activity at the concentrations of 5 and $50 \mathrm{ng} / \mathrm{mL}$.

Therefore, our results show that a de novo expression of CXCR3A in L1.2 cells is sufficient to mediate cell migration in response to PDT stimulation.

\subsection{Pidotimod Induces Migration of IL-2-Activated T Lymphocytes}

Chemokine receptors are specifically and differently expressed on different subsets of leukocytes to control a selective tissue recruitment of functional immune cells [40]. CXCR3 is rapidly induced 
on resting $\mathrm{T}$ cells following activation and plays an important role in $\mathrm{T}$ cell trafficking and function. Therefore, in order to confirm a chemokine-like activity for PDT through the CXCR3 receptor, we performed migration assays with a $5-\mu \mathrm{m}$ Transwell chemotaxis system on IL-2-activated T cells, which express high levels of this receptor on their surface [40], in response to different PDT concentrations $(0.01$, $0.05,0.1,0.5,1,5,25,50 \mu \mathrm{g} / \mathrm{mL})$. As expected, PDT stimulated a statistically significant chemoattraction of IL-2-activated T lymphocytes and its activity occurred at a concentration ranging between 0.05 and $5 \mu \mathrm{g} / \mathrm{mL}$ with a bell-shaped chemotactic dose-response curve and a peak activity at $0.1 \mu \mathrm{g} / \mathrm{mL}$ (2.5-fold increase) (Figure 5H). Moreover, as expected, a strong induction of migration was obtained with IL-2-activated T lymphocytes using CXCL11 $(10 \mathrm{nM})$, a reference chemoattractant for CXCR3 receptor (Figure $5 \mathrm{H}$ ).

Overall, these data show that PDT is able also to stimulate migration of IL-2-activated T lymphocytes.

A

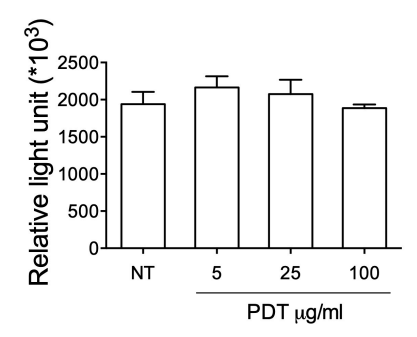

C

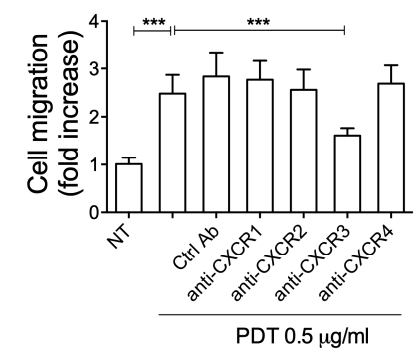

E

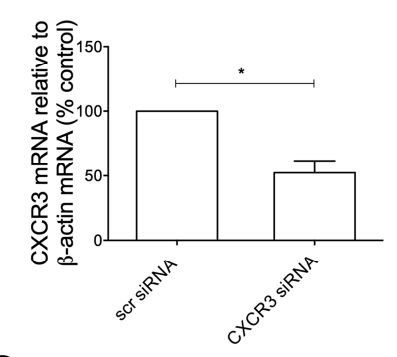

G

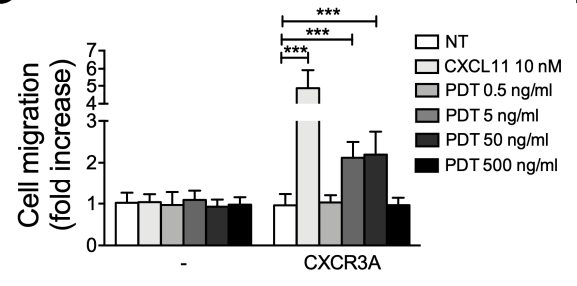

B

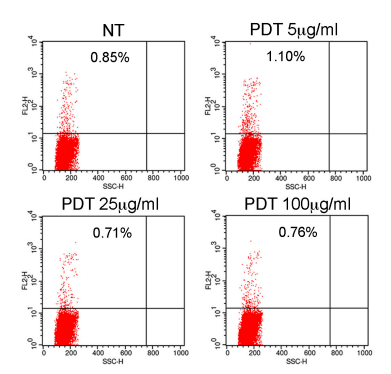

D

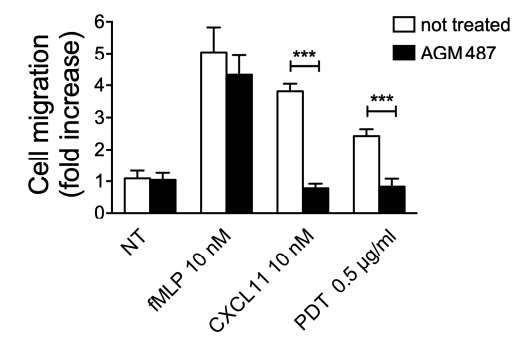

$\mathbf{F}$

H
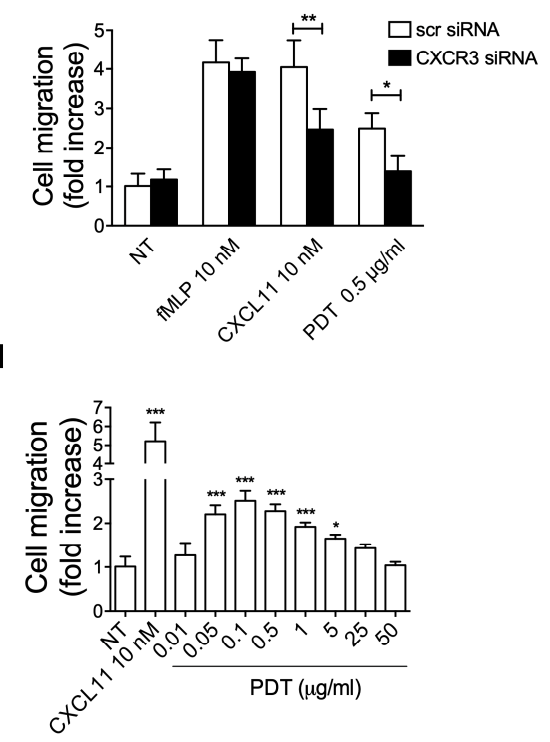

Figure 5. PDT-induced chemotactic activity is mediated by CXCR3. (A) Cells were treated or not (NT) with PDT $(5,25,100 \mu \mathrm{g} / \mathrm{mL})$ for $2 \mathrm{~h}$. Cell viability was assessed on $10^{3}$ cells by CellTiter-Glo ${ }^{\circledR}$ Luminescent Cell Viability Assay, based on determination of intracellular ATP concentration, according 
to manufacturer's instructions. Bars represent the means \pm SD of 3 independent experiments. (B) Cells were treated or not (NT) with PDT $(5,25,100 \mu \mathrm{g} / \mathrm{mL})$ for $2 \mathrm{~h}$, stained with propidium iodide and analyzed by flow cytometer. Data were analyzed by CellQuest software. Figures are representative of one experiment of three with similar results. (C) Transwell migration assay of monocytes in response to the indicated treatments. Monocytes pretreated for $1 \mathrm{~h}$ at $37^{\circ} \mathrm{C}$ with $50 \mu \mathrm{g} / \mathrm{mL}$ of $\mathrm{Ctrl} \mathrm{mAb}$ or mAb to anti-CXCR1 or anti-CXCR2 or anti-CXCR3 or anti-CXCR4 were stimulated for $90 \mathrm{~min}$ at $37^{\circ} \mathrm{C}$ with PBS $(\mathrm{NT})$ or PDT $0.5 \mu \mathrm{g} / \mathrm{mL}$. Bars represent the mean \pm SD of three independent experiments performed in triplicate. Statistical analysis was performed by one-way ANOVA and the Bonferroni's post-test was used to compare data, ${ }^{* * *} p<0.001$. (D) Transwell migration assay of monocytes pretreated for $1 \mathrm{~h}$ at $37^{\circ} \mathrm{C}$ with the inhibitor AGM487 $(0.5 \mu \mathrm{M})$ and stimulated for $90 \mathrm{~min}$ at $37^{\circ} \mathrm{C}$ with PBS (NT), fMLP $(10 \mathrm{nM})$ or CXCL11 $(10 \mathrm{nM})$ or PDT $(0.5 \mu \mathrm{g} / \mathrm{mL})$. Bars represent the means \pm SD of 3 independent experiments performed in triplicate. Statistical analysis was performed by paired 2-tail Student $t$ test, *** $p<0.001$. (E) Analysis of CXCR3 gene expression performed using quantitative real time PCR. Monocytes were nucleoporated with scrambled siRNAs, used as negative control or with a pool of four distinct siRNAs specific for four distinct regions of CXCR3. Analysis of real time PCR data was performed with the $2^{-\Delta \Delta C t}$ method using Relative Quantitation Study software. Quantification of CXCR3 mRNA was normalized in each reaction according to the internal $\beta$-actin control. Bars represent the mean \pm SD of three independent experiments performed in triplicate. (F) Transwell migration assay of monocytes nucleoporated with specific siRNAs for CXCR3 or with scrambled fluorescein-labeled siRNAs (scr siRNA), used as negative control, in response to the indicated treatments. Bars represent the mean \pm SD of three independent experiments performed in triplicate. Statistical analysis was performed by paired two-tail Student's $t$-test, ${ }^{* *} p<0.01,{ }^{*} p<0.05$. NT $=$ not treated (G) Transwell migration assay of L1.2 cells transfected with pTarget empty vector (-) or expressing CXCR3A and stimulated for $90 \mathrm{~min}$ at $37^{\circ} \mathrm{C}$ with PBS (NT), CXCL11 (10 nM) and PDT (0.5, 5, 50, $\left.500 \mathrm{ng} / \mathrm{mL}\right)$. Bars represent the mean $\pm \mathrm{SD}$ of three independent experiments performed in triplicate. Statistical analysis was performed by two-way ANOVA. Bonferroni's post-test was used to compare data, ${ }^{* * *} p<0.001$. (H) Transwell migration assay of IL-2-activated T lymphocytes in response to the indicated treatments. Bars represent the means \pm SD of 3 independent experiments performed in triplicate. Statistical analysis was performed by one-way ANOVA and the Bonferroni's post-test was used to compare data, ${ }^{*} p<0.05$, *** $p<0.001$.

\subsection{CXCL11, as PDT, Triggers Monocyte Migration through Akt Kinase Activation}

Here, we have shown that PDT exerts its chemotactic activity through CXCR3 activation triggering PI3K/Akt signaling pathway. In order to confirm that PDT induces monocyte migration with the same mechanism used by the physiological ligand of CXCR3, CXCL11, we performed monocyte migration assays and western blot analysis. First, monocytes were stimulated or not at $37^{\circ} \mathrm{C}$ for 5 min with CXCL11 (10 nM) and data obtained from western blot analysis show that, as expected, CXCL11 is able to trigger a rapid increase of Tyr phosphorylated proteins (Figure 6A). Then, in order to investigate if the PI3K/Akt signaling pathway, responsible for PDT-induced monocyte recruitment, is also triggered by CXCL11, monocytes were pretreated at $37^{\circ} \mathrm{C}$ with PTx, Akt inhibitor VIII $(1 \mu \mathrm{M})$ and MAPK/ERK inhibitor PD98059 $(10 \mu \mathrm{M})$ and then stimulated with CXCL11 $(10 \mathrm{nM})$ to migrate in a Transwell chemotaxis system. As shown in the Figure 6B, PD98059 did not influence monocyte migration induced by CXCL11, while PTx and the specific Akt inhibitor VIII $(1 \mu \mathrm{M})$ completely inhibited CXCL11-triggered monocyte migration (Figure 4A). Finally, in order to confirm the capability of CXCL11 to activate Akt kinase, we assessed by western blot analysis the Akt phosphorylation status at Ser473 in cytosolic extracts of monocytes, treated for 5, 30 and 60 min with CXCL11 (10 nM). As shown in Figure 6C, monocytes stimulated with CXCL11 for 30 min showed a significant Akt phosphorylation.

Overall, these data show that CXCL11-induced monocyte chemotaxis, like PDT one, is due to the activation of Akt kinase. 
A

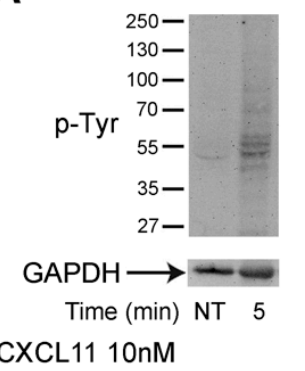

C

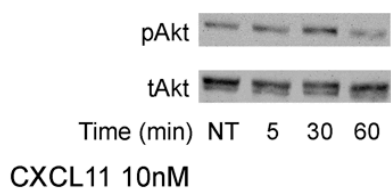

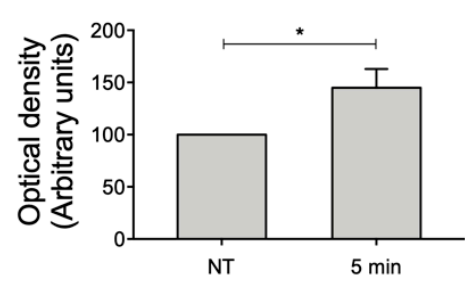

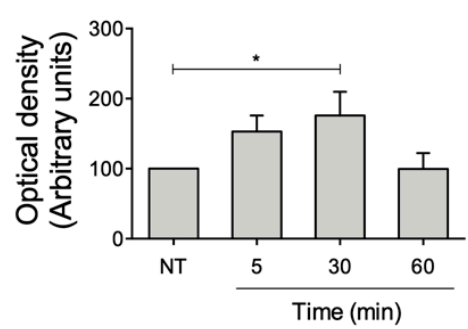

B

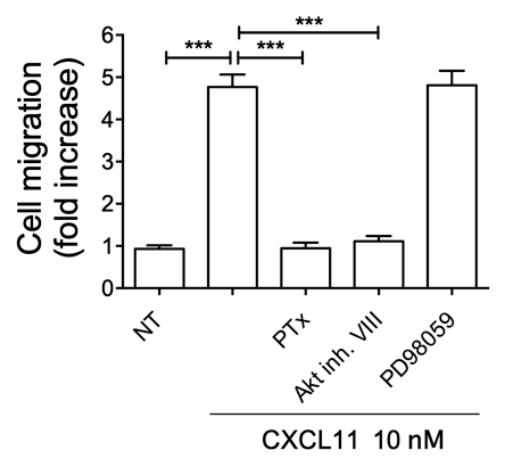

Figure 6. CXCL11-induced chemotactic activity, as PDT one, is mediated by Akt kinase. (A) Monocytes were treated or not for $5 \mathrm{~min}$ with 10nM of CXCL11. Western blot analysis of cells lysates shows that CXCL11 is able to induce an increase of Tyr phosphorylated proteins, as shown by densitometry analysis and plotting of the pTyr/GAPDH. In the left panel blots from one representative experiment of three with similar results are shown. In the right panels, values reported for protein Tyr phosphorylation are the mean \pm SD of three independent experiments. Statistical analysis was performed by Student's $t$-test, ${ }^{*} p<0.05 . \mathrm{NT}=$ not treated. (B) Transwell migration assay of monocytes in response to the indicated treatments. Monocytes pretreated with PTx $(500 \mathrm{ng} / \mathrm{mL})$ or Akt inhibitor VIII $(1 \mu \mathrm{M})$ or PD98059 $(10 \mu \mathrm{M})$ were stimulated for $90 \mathrm{~min}$ at $37^{\circ} \mathrm{C}$ with PBS (NT) or CXCL11 $(10 \mathrm{nM})$. Bars represent the means \pm SD of 3 independent experiments performed in triplicate. Statistical analysis was performed by one-way ANOVA and the Bonferroni's post-test was used to compare data. ${ }^{* * *} p<0.001$. (C) Monocytes were stimulated with $10 \mathrm{nM}$ of CXCL11 at $37^{\circ} \mathrm{C}$ for the indicated times. Not treated cells (NT) were used as control (lane 1). Western blot analysis of monocyte lysates shows that CXCL11 activates Akt, as shown by the respective phosphorylation state, verified by densitometric analysis and plotting of the phospho-Akt/total Akt (pAkt/tAkt). In the left panel blots from one representative experiment of three with similar results are shown. In the right panel, values reported for Akt phosphorylation are the mean \pm SD of three independent experiments. Statistical analysis was performed by one-way ANOVA and the Bonferroni's post-test was used to compare data, ${ }^{*} p<0.05$.

\section{Discussion}

In the present study for the first time we demonstrate that PDT exerts a chemokine-like activity triggering monocyte adhesion and migration. In this regard, PDT can be considered the shortest synthetic peptide known up to date with a chemokine activity.

Our experimental evidences highlight the ability of the dipeptide to functionally activate the $G$ protein-coupled receptor CXCR3, in particular the CXCR3A isoform, which is linked to heterotrimeric GTP-binding proteins of the Gi family. Indeed, PDT-induced chemokine activity was PTx-sensitive and neutralized by an anti-human CXCR3 mAb, a specific CXCR3 inhibitor and CXCR3 siRNA. Moreover, the specificity of CXCR3-mediated effects was confirmed by the capability of dipeptide to chemoattract L1.2 cells stably expressing the human CXCR3A isoform. The study of intracellular signaling downstream of CXCR3 showed that PDT triggers the PI3K/Akt pathway. The activation of such signaling cascade has also been previously observed in response to a wide number of CXCR3 agonists in different cell types and it is in line with the activity previously reported for this canonical receptor [41-43]. 
GPCRs represent one of the therapeutically most relevant protein families and around one-third of the available small-molecule drugs target GPCRs [44]. Surprisingly, PDT, which is simply a dipeptide and doesn't show any amino acid sequence identity with CXCR3 ligands, showed to activate this chemokine receptor. The 3D structure of CXCR3 is currently not known, but a general "two-step" model has been proposed to describe the chemokine receptor activation [45]. The first step is governed by binding of the ligand to the N-terminus and extracellular loops of the GPCR [46], subsequently, the $\mathrm{N}$-terminus of the chemokine is able to interact with the transmembrane domains (TM), leading to activation of the receptor $[45,46]$. In contrast, it is likely that this two-step binding model cannot not be applied in the case of small molecule modulators, like PDT. Indeed, GPCRs possess multiple binding sites and different ligands can selectively stabilize different "active" conformations $[47,48]$. Small molecules, which don't mimic the N-terminal regions of chemokines, rather point out other important interactions and generally bind to the TM part [49,50], as recently shown for example for a small molecule CXCR4 antagonist using X-ray crystallography [51]. In addition, Xanthou et al. (2003) did not validate the two-step model for CXCR3 interactions with its ligands, but instead support a multi-site model, in which multiple and distinct extracellular domains contribute to receptor activation [52]. Consequently, small molecule modulators are considered to allosterically modulate GPCR function from binding sites that are distinct or only partially overlapped with the chemokine interaction points [53-56]. Future studies on PDT structure-activity relationship will be necessary to reveal the modality of dipeptide to trigger CXCR3 and could be of both fundamental and practical relevance.

CXCR3 is known to play a key role in mediating leukocyte recruitment to mucosal tissues and inflammatory sites [57-61]. In particular, different studies demonstrated a key role for CXCR3 in recruitment, trafficking and function of Th1 CD4+ and effector CD8 T cells to infection sites and the establishment on Th1 amplification loop mediated by IFN $\gamma$ and IFN $\gamma$-inducible CXCR3 ligands 61. Moreover, CXCR3 is known to play a role in the migration of $\mathrm{T}$ cells within peripheral tissue and lymphoid compartment, facilitating their interaction with antigen presenting cells and leading to the generation of effector, regulatory and memory $\mathrm{T}$ cells [61]. On the other side, it has been demonstrated that PDT is capable to enhance the proliferation of PBMCs and their production of crucial cytokines, as IFN- $\gamma$ and IL-12 (20), to induce T cell migration (Figure 5E), drive T cell proliferation and differentiation towards a Th1 phenotype [16,19], and induce maturation of dendritic cells (DCs) [18]. In this regard, we can hypothesize that the dipeptide could attract $\mathrm{T}$ cells through the CXCR3 receptor, co-stimulate their proliferation, differentiation and activation, priming $\mathrm{T}$ cell responses with consequent therapeutic implications following local delivery. Moreover, like many chemokines, PDT might direct the migration of circulating leukocytes in the lymphoid tissues regulating and ensure continued recirculation and surveillance of lymphoid tissues. In particular, PDT administration in defined anatomically restricted locations (in vivo) might act as homing molecule in the control of T-cell trafficking over the course of immune response in mucosa-associated lymphoid tissues (MALTs). However, how PDT could be capable of coordinating $\mathrm{T}$ cell responses in the inflamed periphery through CXCR3 remains to be determined and future studies should be aimed at studying the role of this interaction in the control of $\mathrm{T}$ cell function.

Finally, since diverse studies suggested that CXCR3 activation could be beneficial in skin wound healing [62-64] and CXCR3 agonists possess antitumor activity [65-67], it might be interesting to evaluate the use of PDT in different pathological processes. Therefore, from a therapeutic point of view, our demonstration of a chemokine-like activity of PDT through CXCR3, will call for a future exploration of therapeutic potential of using this synthetic dipeptide in different diseases.

\section{Materials and Methods}

\subsection{Pidotimod Preparation}

PDT (purity $>99.6 \%$ ) was a kind gift of Polichem SA (Lugano, $\mathrm{CH}$ ). For all experiments the same PDT stock solution was used $\left(10 \mathrm{mg} / \mathrm{mL}\right.$ in ultrapure endotoxin-free water, stored in aliquots at $\left.-20^{\circ} \mathrm{C}\right)$. 
Biological effects were evaluated using PDT at the final concentrations of $0.01,0.05,0.1,0.5,1,5,25,50$ and $100 \mu \mathrm{g} / \mathrm{mL}$. The absence of endotoxin contamination $(<0.25 \mathrm{unit} / 500 \mu \mathrm{g})$ in the PDT stock solution was assessed by Limulus amoebocyte assay (Associates of Cape Cod, East Falmouth, MA, USA) and all experiments were performed in endotoxin free-condition.

\subsection{Cell Culture}

The murine pre-B L1.2 cells were obtained from the American Type culture collection (Manassas, VA) and cultured in RPMI 1640 containing 10\% fetal bovine serum (FBS, Lonza, Basel, CH), 2 mM L-glutamine, $1 \mathrm{mM}$ sodium pyruvate and $50 \mu \mathrm{M}$ 2-mercaptoethanol (complete medium).

\subsection{Isolation of Human Primary Cells}

Blood was collected from healthy donors who gave informed consent for this research according to the Declaration of Helsinki. PBMCs were isolated by using Ficoll-Paque (Sigma-Aldrich, St. Louis, MO, USA) density gradient centrifugation and then human primary monocytes were isolated from PBMCs by negative selection using the monocyte isolation Kit (Miltenyi Biotec, Bergish Gladbach, NRW, DA) according to the manufacturer's protocol. Monocytes were cultured $\left(2 \times 10^{6} / \mathrm{mL}\right)$ in RPMI 1640 containing 10\% fetal bovine serum (low endotoxin FBS, Lonza) and $2 \mathrm{mM}$ L-glutamine (complete medium). In each experiment, cell purity was evaluated by flow cytometry and was always greater than $97 \%$.

Human primary lymphocytes were isolated from PBMC by Percoll gradient sedimentation, as previously described [68]. T lymphocytes were isolated by negative selection (Miltenyi Biotec) according to manufacturer's instructions. Purity of T lymphocyte preparation was evaluated by flow cytometry after staining with fluorochrome-conjugated anti-CD3 antibodies and was more than 95\%. Isolated T lymphocytes were seeded $\left(2 \times 10^{6} / \mathrm{mL}\right)$ in 6 well plates and kept in culture for 6 days in complete medium supplemented with IL-2 ( $20 \mathrm{ng} / \mathrm{mL}$ ) (R\&D System, Minneapolis, MN, USA) to obtain activated T cells. After 3 days the medium was changed with complete medium containing the cytokine. After 6 days of culture, the cells were harvested, pooled together and counted for the assays.

Monocytes were pretreated for $2 \mathrm{~h}$ at $37^{\circ} \mathrm{C}$, when indicated, with PTx $(500 \mathrm{ng} / \mathrm{mL})$ or $30 \mathrm{~min}$ with LY294002 $(25 \mu \mathrm{M})$ or wortmannin $(100 \mathrm{nM})$ or Akt inhibitor VIII $(1 \mu \mathrm{M})$ (Enzo Life Sciences, Farmingdale, NY, USA) or Tyrphostin AG490 $(10 \mu \mathrm{M})$ (Vinci-Biochem, Firenze, IT) or PD98059 $(10 \mu \mathrm{M})$ or staurosporine (1 nM) (Sigma-Aldrich) or AMG 487 (0.5 $\mu \mathrm{M}$, a CXCR3 antagonist) (Tocris Bioscience, Bristol, GB) or with a control IgG antibody and a neutralizing mAb to CXCR1 (MAb330) or CXCR2 (MAb331) or CXCR3 (MAb160) or CXCR4 (MAb171) (50 $\mu \mathrm{g} / \mathrm{mL})$ (R\&D System).

\subsection{Chemotaxis Assays}

Migration of monocytes, T lymphocytes and L1.2 cells was assessed using 5 - $\mu \mathrm{m}$ pore-size Transwells (BD Biosciences, Franklin Lakes, NJ, USA). Chemotaxis assays were performed as previously described [27]. Briefly, cells, pre-treated or not with PTx or different inhibitors, were suspended at $2 \times 10^{6} / \mathrm{mL}$ in adhesion buffer. Cell suspension $(100 \mu \mathrm{L})$ was added to the top well and adhesion buffer $(600 \mu \mathrm{L})$ containing Pidotimod $(0.01,0.05,0.1,0.5,1,5,25$ and $50 \mu \mathrm{g} / \mathrm{mL})$ to the bottom well. LPC (L- $\alpha$-lysophosphatidylcholine, palmitoyl C16:0, Sigma-Aldrich) $(10 \mu \mathrm{M})$ and fMLP $(10 \mathrm{nM})$ were also used as reference chemoattractants to evaluate the selective and not toxic effect of PTx; CXCL8, CXCL11 and CXCL12 (R\&D System) $(10 \mathrm{nM})$ were used as chemokine ligands to evaluate the specificity of antibodies. Chemotaxis was performed for $90 \mathrm{~min}$ at $37^{\circ} \mathrm{C}$ and then filters were removed. After fixation with $1.5 \%$ paraformaldehyde, migrated cells were counted in 5 high-power fields by light microscopy at a 10× magnification. Results are expressed as the fold increase compared with control.

\subsection{Static Adhesion Assay}

Adhesion assays were performed as previously described [27]. Monocytes, pre-treated or not with PTx, were suspended at $5 \times 10^{6} / \mathrm{mL}$ in adhesion buffer (PBS, $1 \mathrm{mM} \mathrm{CaCl}_{2}, 1 \mathrm{mM} \mathrm{MgCl}_{2}, 10 \%$ 
FCS, pH 7.2) and $20 \mu \mathrm{L}$ of cell suspension was added to 18-well glass slides (Thermo Fisher Scientific, Waltham, MA, USA) coated overnight at $4{ }^{\circ} \mathrm{C}$ with ICAM- 1 and V-CAM $(1 \mu \mathrm{g} / \mathrm{mL}$, R\&D Systems). Cells were then stimulated for $2 \mathrm{~min}$ at $37^{\circ} \mathrm{C}$ with $5 \mu \mathrm{L}$ of PDT at different concentrations $(1,5,10$, $50,100 \mu \mathrm{g} / \mathrm{mL}$ ). PMA (phorbol 12-myristate 13-acetate) stimulation $(100 \mathrm{ng} / \mathrm{mL})$ at $37^{\circ} \mathrm{C}$ for $10 \mathrm{~min}$ was also evaluated to exclude a toxic effect of PTx. After washing, adherent cells were fixed in $1.5 \%$ glutaraldehyde. Computer-assisted enumeration of cells in 4 high-power fields by light microscopy was performed. Results are expressed as the -fold increase compared with control.

\subsection{Western Blot Analysis}

Monocytes $\left(10 \times 10^{6} / \mathrm{mL}\right)$ were stimulated with fMLP $(10 \mathrm{nM})$ and PDT at different concentrations $1,5,25,50,100 \mu \mathrm{g} / \mathrm{mL}$ and then lysed in $200 \mu \mathrm{L}$ of buffer (pH 7.2) containing $20 \mathrm{mM}$ MOPS (pH 7.0), 2 mM EGTA, 5 mM EDTA, $30 \mathrm{mM}$ sodium fluoride, $60 \mathrm{mM}$ glycerophosphate ( $\mathrm{pH} 7.2), 20 \mathrm{mM}$ sodium pyrophosphate, $1 \mathrm{mM}$ sodium orthovanadate, $1 \mathrm{mM}$ Dithiothreitol (DTT), $1 \%$ Triton X-100 and a mixture of protease inhibitors (Complete Mini Roche, Hoffmann-La Roche, Basel, $\mathrm{CH}$ ). The total concentration of proteins was detected by QuantiProTM BCA Assay (Sigma-Aldrich). Equal amounts of total protein were resolved on a $12 \%$ SDS-polyacrylamide gel and then electroblotted using PVDF (polyvinylidene difluoride) membrane. The blots were incubated overnight at $4{ }^{\circ} \mathrm{C}$ with 1) mouse monoclonal p-Tyr antibody (PY99) (Santa Cruz Biotechnology, Dallas, TX, USA), 2) rabbit polyclonal phospho-Akt (Ser473) antibody (Santa Cruz Biotecnology), 3) mouse monoclonal Akt antibody (Cell Signaling Technology, Danvers, MA, USA), 4) rabbit polyclonal antibody to ERK1/2 (Santa Cruz Biotechnology), 5) mouse monoclonal GADPH antibody (Santa Cruz Biotechnology). Antigen-antibody complexes were revealed by incubating the membranes at room temperature for $1 \mathrm{~h}$ with peroxidase-conjugated anti-mouse or anti-rabbit antibodies (Thermo Fisher Scientific) and using the ECL (Enhanced Chemiluminescence) System (Santa Cruz Biotechnology). The images were captured by ChemiDoc-It Imaging System and the integrated optical density (IOD) was determined using the Gel-Pro Analyzer 6.0 software (Houston, TX, USA.

\section{7. siRNA Technique}

Monocytes were nucleoporated (program Y-001) with specific siRNAs for CXCR3 receptor (Origene, Rockville, MD, USA) using the Amaxa Nucleofector System (Amaxa Biosystems, Cologne, NW, DE). In particular, siRNAs $(100 \mathrm{nM})$ were added to $3 \times 10^{6}$ cells resuspended in $100 \mathrm{~mL}$ of nucleofection buffer. Fluorescein-labeled irrelevant (scr) siRNAs (Invitrogen, Carisbad, CA, USA) were used as negative control and to assess the efficiency of siRNA nucleoporation by flow cytometry. The efficacy of CXCR3 siRNA was evaluated by real-time PCR analysis.

\subsection{Real-Time PCR for Gene Expression Analysis}

Total RNA was isolated from monocytes $\left(1 \times 10^{6}\right.$ cells) using RNeasy Plus Mini Kit (Qiagen, Valencia, CA, USA). Following retrotranscription, $50 \mathrm{ng}$ of cDNA mixed with sterile water and SYBR Green qPCR Master Mix (Promega, Madison, WI, USA) were amplified using the PrimeTime qPCR primer Assay for CXCR3 and the following PCR primers $\left(0.2 \mu \mathrm{M}\right.$ each): human $\beta$ actin, $5^{\prime}-$ GGCACCCAGCACAATGAAG -3' (forward), and 5'- GCTGATCCACATCTGCTGG -3' (reverse) (Integrated DNA technologies, Coralville, IA, USA). Quantification of CXCR3 cDNA was normalized in each reaction according to the internal $\beta$-actin control. Results are expressed as percentage of control.

\subsection{Cell Viability Assay}

Cell viability was evaluated according to the manufacturer's instructions by CellTiter-Glo Luminescent Cell Viability Assay (Promega), which is based on the quantification of ATP. The same number of treated (PDT 5, 25, $100 \mu \mathrm{g} / \mathrm{mL}$ ) and not treated cells for $120 \mathrm{~min}$ were analyzed. 


\subsection{Flow Cytometry Analysis}

Cell integrity was analyzed by flow cytometry. In brief, treated (PDT 5, 25, $100 \mu \mathrm{g} / \mathrm{mL}$ ) or not treated cells with PDT were harvested, washed with phosphate-buffered saline (PBS) and pelleted by centrifugation. Then, the cells were stained for nuclear DNA content with $50 \mu \mathrm{g} / \mathrm{mL}$ propidium iodide (PI) (Sigma-Aldrich). Determination of PI-stained cells was performed in FL-2A channel on FACSCalibur flow cytometer and data were acquired and analyzed by using CellQuest Software (BD Bioscience).

\subsection{Transfections}

Murine pre-B cells L1.2 were cultured in RPMI 1640 containing $1 \mathrm{mM} \mathrm{L-glutamine,} 1 \mathrm{mM}$ sodium pyruvate, $10 \%$ FBS and $50 \mu \mathrm{M}$ 2-mercaptoethanol. Transfections of L1.2 cells were performed using Amaxa nucleofector (Lonza) (program U-015), according to the manufacturer's instructions. Cells were plated at $1 \times 10^{6} / \mathrm{mL}$ and, after $24 \mathrm{~h}, 4 \times 10^{6}$ cells were nucleofected with $3 \mathrm{mg}$ endotoxin-free plasmids pTarget or pTarget-CXCR3A. The vector pTarget was from Promega and was used as negative control. In pTarget-CXCR3A construct (a kind gift from Alan Wells, Department of Pathology, University of Pittsburgh, Pittsburgh, Pennsylvania, USA) CXCR3A (NM_001504.1) was cloned into the EcoRI and Sall sites of pTarget. After $4 \mathrm{~h}$ from transfection, in order to enhance CXCR3A cell surface expression, transient transfectants were incubated overnight at $37^{\circ} \mathrm{C}$ in medium supplemented with $10 \mathrm{mM}$ sodium butyrate (Sigma-Aldrich). The transfection efficiency was evaluated as GFP expression by flow cytometry using control vector pmaxGFP included in Amaxa nucleofector kit. Cell surface expression of CXCR3A was evaluated by flow cytometry using an anti-human CXCR3 PE-conjugated $\mathrm{mAb}$ (Thermo Fisher Scientific).

\subsection{Statistical Analysis}

Data obtained from multiple independent experiments are expressed as the means \pm the standard deviations (SD). The data were analyzed for statistical significance using a paired 2-tail Student $t$ test or one-way ANOVA. Bonferroni's post-test was used to compare data. Differences were considered significant at $p<0.05$. Statistical tests were performed using Prism 5 software (GraphPad Software, La Jolla, CA, USA).

Supplementary Materials: Supplementary materials can be found at http://www.mdpi.com/1422-0067/20/21/ $5287 / \mathrm{s} 1$.

Author Contributions: Conceptualization, F.C. and C.G.; formal analysis, F.C., A.B, S.C., S.R., A.Z., P.M., S.M., C.G; investigation, F.C., A.B., S.C., S.R., P.M. and A.Z.; methodology, F.C., A.B., and C.G.; project administration, A.C.; supervision, F.C. and C.G.; writing—original draft, C.G.; writing—review and editing, A.C.

Funding: This research received no external funding.

Acknowledgments: We thank Alan Wells, (Department of Pathology, University of Pittsburgh, Pittsburgh, Pennsylvania, USA) for supplying pTarget-CXCR3A construct. This study was kindly supported by Polichem SA, Lugano, Switzerland.

Conflicts of Interest: The authors declare no conflict of interest.

\section{References}

1. Griffin, M.R.; Walker, F.J; Iwane, M.K.; Weinberg, G.A.; Staat, M.A.; Erdman, D.D. Epidemiology of respiratory infections in young children: Insights from the new vaccine surveillance network. Pediatr. Infect. Dis. J. 2004, 23, 188-192. [CrossRef] [PubMed]

2. Schaad, U.B. OM-85 BV, an immunostimulant in pediatric recurrent respiratory tract infections: A systematic review. World J. Pediatr. 2010, 6, 5-12. [CrossRef] [PubMed]

3. Rozy, A.; Chorostowska-Wynimko, J. Bacterial immunostimulants-mechanism of action and clinical application in respiratory diseases. Pneumonol. Alergol. Pol. 2008, 76, 353-359. [PubMed] 
4. Ounis, I. Determination of the antiinfectious activity of RU 41740 (Biostim) as an example of an immunomodulator. Adv. Exp. Med. Biol. 1992, 319, 165-174. [PubMed]

5. Fiocchi, A.; Terracciano, L.; Martelli, A.; Bernardo, L.; Calcinai, E.; Marcassa, S. Ribosome-component immune modulation of respiratory tract infections in children. Allergy Asthma Proc. 2009, 30, 21-31. [CrossRef] [PubMed]

6. Lavigne, P.; LeeS, E. Immunomodulators Chronic Rhinosinusitis. World J. Otorhinolaryngol. Head Neck Surg. 2018, 4, 186-192. [CrossRef]

7. Masihi, K.N. Fighting infection using immunomodulatory agents. Expert Opin. Biol. Ther. 2001, 1, $641-653$. [CrossRef]

8. Burgio, G.R.; Marseglia, G.L.; Severi, F.; de Benedetti, F.; Masarone, M.; Ottolenghi, A.; Pagliano, L.; Serra, U.; Nespoli, L. Immunoactivation by pidotimod in children with recurrent respiratory infections. Arzneimittelforschung 1994, 44, 1525-1529.

9. Esposito, S.; Musio, A. Immunostimulants and prevention of recurrent respiratory tract infections. J. Biol. Regul. Homeost. Agents 2013, 27, 627-636.

10. Motta, G.; De Campora, E.; de Vita, C.; Esposito, S.; Galletti, C.; Incutti, V.; Mallardi, V.; Motta, S.; Pucci, V.; Salonna, F. Immunoactivity of Pidotimod against episodes of recurrent tonsillitis in childhood. Arzneimittelforschung 1994, 44, 1521-1524.

11. Careddu, P.; Mei, V.; Venturoli, V.; Corsini, A. Pidotimod in the treatment of recurrent respiratory infections in paediatric patients. Arzneimittelforschung 1994, 44, 1485-1489. [PubMed]

12. Caramia, G.; Clemente, E.; Solli, R.; Mei, V.; Cera, R.; Carnelli, V.; Venturoli, V.; Corsini, A. Efficacy and safety of Pidotimod in the treatment of recurrent respiratory infections in children. Arzneimittelforschung 1994, 44, 1480-1484. [PubMed]

13. Passali, D.; Calearo, C.; Conticello, S. Pidotimod in the management of recurrent pharyngotonsillar infections in childhood. Arzneimittelforschung 1994, 44, 1511-1516. [PubMed]

14. La Mantia, I.; Grillo, C.; Mattina, T.; Zaccone, P.; Xiang, M.; Di Mauro, M.; Meroni, P.L.; Nicoletti, F. Prophylaxis with the novel immunomodulator Pidotimod reduces the frequency and severity of upper respiratory tract infections in children with Down's syndrome. J. Chemother. 1999, 11, 126-130. [CrossRef]

15. Riboldi, P.; Gerosa, M.; Meroni, P.L. Pidotimod: A reappraisal. Int. J. Immunopathol. Pharmacol. 2009, 22, 255-362. [CrossRef]

16. Auteri, A.; Pasqui, A.L.; Bruni, F.; Saletti, M.; Di Renzo, M.; Bova, G. Effect of Pidotimod, a new immunostimulating agent, on some aspects of immune response. Vitr. Study. Pharmacol. Res. 1992, 26, 196-197. [CrossRef]

17. Migliorati, G.; Nicoletti, I.; Riccardi, C. Immunomodulating activity of Pidotimod. Arzneimittelforschung 1994, 44, 1421-1424.

18. Giagulli, C.; Noerder, M.; Avolio, M.; Becker, P.; Fiorentini, S.; Guzman, C.; Caruso, A. Pidotimod promotes functional maturation of dendritic cells and displays adjuvant properties at the nasal mucosa level. Int. Immunopharmacol. 2009, 9, 1366-1373. [CrossRef]

19. Zuccotti, G.V.; Mameli, C. Pidotimod: The past and the present. J. Pediatrics 2013, 39, 75-78. [CrossRef]

20. Di Renzo, M.; Pasqui, A.L.; Bruni, F.; Saletti, M.; Bova, G.; Chiaron, C.; Girardello, R.; Ferri, P.; Auteri, A. The in vitro effect of Pidotimod on some immune functions in cancer patients. Immunopharmacol. Immunotoxicol. 1997, 19, 37-51. [CrossRef]

21. Fogli, M.; Caccuri, F.; Iaria, M.L.; Giagulli, C.; Corbellini, S.; Campilongo, F.; Caruso, A.; Fiorentini, S. The immunomodulatory molecule Pidotimod induces the expression pf the nod-like receptor NLRP12 and attenuates TLR-induced inflammation. J. Biol. Regul. Homeost. Agents 2014, 28, 753-766. [PubMed]

22. Mertens, I.; Vandingenen, A.; Meeusen, T.; de Loof, A.; Schoofs, L. Postgenomic characterization of G-protein-coupled receptors. Pharmacogenomics 2004, 5, 657-672. [CrossRef] [PubMed]

23. Weiss, A.; Littman, D.R. Signal transduction by lymphocyte antigen receptors. Cell 1994, 76, $263-274$. [CrossRef]

24. Seet, B.T.; Dikic, L.; Zhou, M.M.; Pawson, T. Reading protein modifications with interaction domains. Nat. Rev. Mol. Cell Biol. 2006, 7, 473-483. [CrossRef]

25. Laudanna, C.; Kim, J.Y.; Constantin, G.; Butcher, E. Rapid leukocyte integrin activation by chemokines. Immunol. Rev. 2002, 186, 37-46. [CrossRef] 
26. Campbell, J.J.; Qin, S.; Bacon, K.B.; Mackay, C.R.; Butcher, E.C. Biology of chemokine and classical chemoattractant receptors: Differential requirements for adhesion-triggering versus chemotactic responses in lymphoid cells. J. Cell Biol. 1996, 134, 255-266. [CrossRef]

27. Giagulli, C.; Magiera, A.; Bugatti, A.; Caccuri, F.; Marsico, S.; Rusnati, M.; Vermi, W.; Fiorentini, S.; Caruso, A. HIV-1 matrix protein p17 binds to the IL-8 receptor CXCR1 and shows IL-8-like chemokine activity on monocytes through Rho/ROCK activation. Blood 2012, 119, 2274-2283. [CrossRef]

28. Sozzani, S.; Luini, W.; Molino, M.; Jílek, P.; Bottazzi, B.; Cerletti, C.; Matsushima, K.; Mantovani, A. The signal transduction pathway involved in the migration induced by a monocyte chemotactic cytokine. J. Immunol. 1991, 147, 2215-2221.

29. Fontana, L.; Giagulli, C.; Minuz, P.; Lechi, A.; Laudanna, C. 8-Iso-PGF2 alpha induces beta 2-integrin-mediated rapid adhesion of human polymorphonuclear neutrophils: A link between oxidative stress and ischemia/reperfusion injury. Arterioscler. Thromb. Vasc. Biol. 2001, 21, 55-60. [CrossRef]

30. Schilling, T.; Eder, C. Lysophosphatidylcholine- and MCP-1-induced chemotaxis of monocytes requires potassium channel activity. Pflug. Arch. 2009, 459, 71-77. [CrossRef]

31. Welf, E.S.; Haugh, J.M. Signaling pathways that control cell migration: Models and analysis. Wiley Interdiscip. Rev. Syst. Biol. Med. 2011, 3, 231-240. [CrossRef] [PubMed]

32. Finlay, D.; Cantrell, D. Phosphoinositide 3-kinase and the mammalian target of rapamycin pathways control T cell migration. Ann. N. Y. Acad. Sci. 2010, 1183, 149-157. [CrossRef] [PubMed]

33. Xue, G.; Zippelius, A.; Wicki, A.; Mandalà, M.; Tang, F.; Massi, D.; Hemmings, B.A. Integrated Akt7PKB signaling in immunomodulation and its potential role in cancer immunotherapy. J. Natl. Cancer Inst. 2015, $11,107$.

34. Xue, G.; Hemmings, B.A. PKB/Akt-dependent regulation of cell motility. J. Natl. Cancer Inst. 2013, 105, 393-404. [CrossRef] [PubMed]

35. Le Duc, D.; Schulz, A.; Lede, V.; Schulze, A.; Thor, D.; Brüser, A.; Schöneberg, T. P2Y Receptors in Immune Response and Inflammation. Adv. Immunol. 2017, 136, 85-121. [PubMed]

36. Gerszten, R.E.; Garcia-Zepeda, E.A.; Lim, Y.C.; Yoshida, M.; Ding, H.A.; Gimbrone, M.A., Jr.; Luster, A.D.; Luscinskas, F.W.; Rosenzweig, A. MCP-1 and IL-8 trigger firm adhesion of monocytes to vascular endothelium under flow conditions. Nature 1999, 398, 718-723. [CrossRef]

37. Struckhoff, A.P.; Vitko, J.R.; Rana, M.K.; Davis, C.T.; Foderingham, K.E.; Liu, C.H.; Vanhoy-Rhodes, L.; Elliot, S.; Zhu, Y.; Burow, M.; et al. Dynamic regulation of ROCK in tumor cells controls CXCR4-driven adhesion events. J. Cell Sci. 2010, 123, 401-412. [CrossRef]

38. Costa, C.; Traves, S.L.; Tudhope, S.J.; Fenwick, P.S.; Belchamber, K.B.; Russell, R.E.; Barne, P.J.; Donnelly, L.E. Enhanced monocyte migration to CXCR3 and CCR5 chemokines in COPD. Eur. Respir. J. 2016, 47, 1093-1102. [CrossRef]

39. Billottet, C.; Quemener, C.; Bikfalvi, A. CXCR3, a double-edged sword in tumor progression and angiogenesis. Biochim. Biophys. Acta 2013, 1836, 287-295. [CrossRef]

40. Lasagni, L.; Francalanci, M.; Annunziato, F.; Lazzeri, E.; Giannini, S.; Cosmi, L.; Sagrinati, C.; Mazzinghi, B.; Orlando, C.; Maggi, E.; et al. An alternatively spliced variant of CXCR3 mediates the inhibition of endothelial cell growth induced by IP-10, Mig, and I-TAC, and acts as functional receptor for platelet factor 4. J. Exp. Med. 2003, 197, 1537-1549. [CrossRef]

41. Sallusto, F.; Mackay, C.R. Chemoattractants and their receptors in homeostasis and inflammation. Curr. Opin. Immunol. 2004, 16, 724-731. [CrossRef] [PubMed]

42. Bonacchi, A.; Romagnani, P.; Romanelli, R.G.; Efsen, E.; Annunziato, F.; Lasagni, L.; Francalanci, M.; Serio, M.; Laffi, G.; Pinzani, M.; et al. Signal transduction by the chemokine receptor CXCR3: Activation of Ras/ERK, Src, and phosphatidylinositol 3-kinase/Akt controls cell migration and proliferation in human vascular pericytes. J. Biol. Chem. 2001, 276, 9945-9954. [CrossRef] [PubMed]

43. Korniejewska, A.; McKnight, A.J.; Johnson, Z.; Watson, M.L.; Ward, S.G. Expression and agonist responsiveness of CXCR3 variants in human T lymphocytes. Immunology 2011, 132, 503-515. [CrossRef] [PubMed]

44. Scholten, D.J.; Canals, M.; Wijtmans, M.; de Munnik, S.; Nguyen, P.; Verzijl, D.; de Esch, I.J.; Vischer, H.F.; Smit, M.J.; Leurs, R. Pharmacological characterization of a small-molecule agonist for the chemokine receptor CXCR3. Br. J. Pharmacol. 2012, 166, 898-911. [CrossRef] 
45. Overington, J.P.; Al-Lazikani, B.; Hopkins, A.L. How many drug targets are there? Nat. Rev. Drug Discov. 2006, 5, 993-996. [CrossRef]

46. Kufareva, I.; Salanga, C.L.; Handel, T.M. Chemokine and chemokine receptor structure and interactions: Implications for therapeutic strategies. Immunol. Cell Biol. 2015, 93, 372-383. [CrossRef]

47. Allen, J.A.; Halverson-Tamboli, R.A.; Rasenick, M.M. Lipid raft microdomains and neurotransmitter signaling. Nat. Rev. Neurosci. 2007, 8, 128-140. [CrossRef]

48. Kenakin, T. Collateral efficacy in drug discovery: Taking advantage of the good (allosteric) nature of 7TM receptors. Trends Pharmacol. Sci. 2007, 28, 407-415. [CrossRef]

49. Baker, J.G.; Hill, S.J. Multiple GPCR conformations and signaling pathways: Implications for antagonist affinity estimates. Trends Pharmacol. Sci. 2007, 28, 374-381. [CrossRef]

50. Blanpain, C.; Doranz, B.J.; Bondue, A.; Govaerts, C.; De Leener, A.; Vassart, G.; Doms, R.W.; Proudfoot, A.; Parmentier, $\mathrm{M}$. The core domain of chemokines binds CCR5 extracellular domains while their amino terminus interacts with the transmembrane helix bundle. J. Biol. Chem. 2003, 101, 746-754. [CrossRef]

51. Kofuku, Y.; Yoshiura, C.; Ueda, T.; Terasawa, H.; Hirai, T.; Tominaga, S.; Hirose, M.; Maeda, Y.; Takahashi, H.; Terashima, Y.; et al. Structural basis of the interaction between chemokine stromal cell-derived factor-1/CXCL12 and its G-protein-coupled receptor CXCR4. J. Biol. Chem. 2009, 284, 35240-35250. [CrossRef] [PubMed]

52. Wu, B.; Chien, E.Y.; Mol, C.D.; Fenalti, G.; Liu, W.; Katritch, V.; Abagyan, R.; Brooun, A.; Wells, P.; Bi, F.C.; et al. Structures of the CXCR4 chemokine GPCR with small-molecule and cyclic peptide antagonists. Science 2010, 330, 1066-1071. [CrossRef] [PubMed]

53. Xanthou, G.; Williams, T.J.; Pease, J.E. Molecular characterization of the chemokine receptor CXCR3: Evidence for the involvement of distinct extracellular domains in a multi-step model of ligand binding and receptor activation. Eur. J. Immunol. 2003, 33, 2927-2936. [CrossRef] [PubMed]

54. Kondru, R.; Zhang, J.; Ji, C.; Mirzadegan, T.; Rotstein, D.; Sankuratri, S.; Dioszegi, M. Molecular interactions of CCR5 with major classes of small-molecule anti-HIV CCR5 antagonists. Mol. Pharmacol. 2008, 73, 789-800. [CrossRef] [PubMed]

55. Verzijl, D.; Storelli, S.; Scholten, D.J.; Bosch, L.; Reinhart, T.A.; Streblow, D.N.; Tensen, C.P.; Fitzsimons, C.P.; Zaman, G.J.; Pease, J.E.; et al. Noncompetitive antagonism and inverse agonism as mechanism of action of nonpeptidergic antagonists at primate and rodent CXCR3 chemokine receptors. J. Pharmacol. Exp. Ther. 2008, 325, 544-555. [CrossRef]

56. De Kruijf, P.; van Heteren, J.; Lim, H.; Conti, P.; van der Lee, M.; Bosch, L.; Ho, K.K.; Auld, D.; Ohlmeyer, M.; Smit, M.J.; et al. Nonpeptidergic allosteric antagonists differentially bind to the CXCR2 chemokine receptor. J. Pharmacol. Exp. Ther. 2009, 329, 783-790. [CrossRef]

57. Garcia-Perez, J.; Rueda, P.; Staropoli, I.; Kellenberger, E.; Alcami, J.; Arenzana-Seisdedos, F.; Lagane, B. New insights into the mechanisms whereby low molecular weight CCR5 ligands inhibit HIV-1 infection. J. Biol. Chem. 2011, 286, 4978-4990. [CrossRef]

58. Qin, S.; Rottman, J.B.; Myers, P.; Kassam, N.; Weinblatt, M.; Loetscher, M.; Koch, A.E.; Moser, B.; Mackay, C.R. The chemokine receptors CXCR3 and CCR5 mark subsets of T cells associated with certain inflammatory reactions. J. Clin. Invest. 1998, 101, 746-754. [CrossRef]

59. Cella, M.; Jarrossay, D.; Facchetti, F.; Alebardi, O.; Nakajima, H.; Lanzavecchia, A.; Colonna, M. Plasmacytoid monocytes migrate to inflamed lymph nodes and produce large amounts of type I interferon. Nat. Med. 1999, 5, 919-923. [CrossRef]

60. Thomas, S.Y.; Hou, R.; Boyson, J.E.; Means, T.K.; Hess, C.; Olson, D.P.; Strominger, J.L.; Brenner, M.B.; Gumperz, J.E.; Wilson, S.B.; et al. CD1d-restricted NKT cells express a chemokine receptor profile indicative of Th1-type inflammatory homing cells. J. Immunol. 2003, 171, 2571-2580. [CrossRef]

61. Nanki, T.; Takada, K.; Komano, Y.; Morio, T.; Kanegane, H.; Nakajima, A.; Lipsky, P.E.; Miyasaka, N. Chemokine receptor expression and functional effects of chemokines on B cells: Implication in the pathogenesis of rheumatoid arthritis. Arthritis Res. Ther. 2009, 11, R149. [CrossRef] [PubMed]

62. Groom, J.R.; Luster, A.D. CXCR3 in T cell function. Exp. Cell Res. 2011, 317, 620-631. [CrossRef] [PubMed]

63. Yates, C.C.; Whaley, D.; Kulasekeran, P.; Hancock, W.W.; Lu, B.; Bodnar, R.; Newsome, J.; Hebda, P.A.; Wells, A. Delayed and deficient dermal maturation in mice lacking the CXCR3 ELR-negative CXC chemokine receptor. Am. J. Pathol. 2007, 171, 484-495. [CrossRef] [PubMed] 
64. Yates, C.C.; Whaley, D.; Y-Chen, A.; Kulasekeran, P.; Hebda, P.A.; Wells, A. ELR-negative CXC chemokine CXCL11 (IP-9/I-TAC) facilitates dermal and epidermal maturation during wound repair. Am. J. Pathol. 2008, 173, 643-652. [CrossRef] [PubMed]

65. Yates, C.C.; Whaley, D.; Hooda, S.; Hebda, P.A.; Bodnar, R.J.; Wells, A. Delayed reepithelialization and basement membrane regeneration after wounding in mice lacking CXCR3. Wound Repair Regen. 2009, 17, 34-41. [CrossRef] [PubMed]

66. Luster, A.D.; Leder, P. IP-10, a-C-X-C- chemokine, elicits a potent thymus-dependent antitumor response in vivo. J. Exp. Med. 1993, 178, 1057-1065. [CrossRef] [PubMed]

67. Sgadari, C.; Farber, J.M.; Angiolillo, A.L.; Liao, F.; Teruya-Feldstein, J.; Burd, P.R.; Yao, L.; Gupta, G.; Kanegane, C.; Tosato, G. Mig, the monokine induced by interferon-gamma, promotes tumor necrosis in vivo. Blood 1997, 89, 2635-2643. [CrossRef]

68. Hensbergen, P.J.; Wijnands, P.G.; Schreurs, M.W.; Scheper, R.J.; Willemze, R.; Tensen, C.P. The CXCR3 targeting chemokine CXCL11 has potent antitumor activity in vivo involving attraction of CD8+ T lymphocytes but not inhibition of angiogenesis. J. Immunother. 2005, 28, 343-351. [CrossRef]

(C) 2019 by the authors. Licensee MDPI, Basel, Switzerland. This article is an open access article distributed under the terms and conditions of the Creative Commons Attribution (CC BY) license (http://creativecommons.org/licenses/by/4.0/). 